\title{
Psikolojik Şiddet Algısı, Tükenmişlik Sendromu Ve İşten Ayrılma Niyeti Arasındaki İlişki: Banka Çalışanları Üzerinde Bir Araştırma
}

\author{
Haluk TANRIVERDİ* Gelengül KOÇASLAN** \\ Nurdan OSMANOĞLU TAŞTAN****
}

\begin{abstract}
$\ddot{O} Z$
Bu çalışmanın amacı, iş hayatındaki rekabet ortamından en çok etkilenen kurumlardan biri olan bankalarda; psikolojik şiddet, tükenmişlik sendromu ve işten ayrllma niyeti arasındaki ilişkileri araştırmak ve alınacak önlemler ile bu alanda bir farkindalık yaratmaktır.

Çalışma 243 banka çalışanının katıldığı; psikolojik şiddet algısı, tükenmişlik sendromu ve işten ayrılma niyetini araştıran bir anket içermektedir. Sözkonusu kavramlar arasındaki ilişkiler SPSS programı yardımıyla analiz edilmiş; elde edilen veriler frekans, faktör ve regresyon analizlerinde kullanilmıștır.

Çalışmada elde edilen sonuçlara göre; bankacıların genel tükenmişlik düzeyleri ve genel psikolojik şiddet algıları işten ayrılma niyetlerini, genel psikolojik şiddet algısı da genel tükenmişlik düzeyini etkilemektedir.
\end{abstract}

Anahtar Kelimeler:Psikolojik Şiddet, Tükenmişlik Sendromu, Işsten Ayrllma Niyeti

JEL Kodlart: D23, M12, M54, G21, J28, J63.

The Relation Between The Perception Of Psychologicalviolence (Mobbing) , Burnout Syndrome And Intentıon To Leave: A Research On The Bank Employees

\begin{abstract}
The aim of this study is to search the relationship between psychological violence, burnout syndrome and intention to leave in the banks as one of the most affected institutions by the competitive environment, to determine underlying results and to create awareness by taking precautions in the field.

The study includes a survey searching the perception of psychological violence, burnout syndrome and intention to leave where 243 bank employees took part. Relations between these concepts are analyzed by SPSS 18; obtained datas are used in factor, correlation, regression, frequency analysis.

According to the results of the study, the general psychological violance level and the burnout level effect the the rate of intention to leave and the general psychological violance level also effects burnout level.
\end{abstract}

Keywords: Psychological Violence, Burnout Syndrome, Intention to Leave

JEL Codes: D23, M12, M54, G21, J28, J63.

\footnotetext{
*Prof. Dr. İstanbul Üniversitesi, İktisat Fakültesi, Turizm İşletmeciliği Bölümü. email: haluktanriverdi34@gmail.com

** Doç. Dr. İstanbul Üniversitesi, İktisat Fakültesi, İngilizce İktisat Bölümü. email: kocaslan@istanbul.edu.tr

${ }^{* * *}$ Uz. Kuveyttürk Derince Şubesi, Operasyon Yönetmeni, email: n_osmanoglu@ hotmail.com
} 
Haluk Tanrıverdi \& Gelengül Koçaslan \& Nurdan Osmanoğlu Taştan / Psikolojik Şiddet Algısl, Tükenmişlik Sendromu Ve İsten Ayrılma Niyeti Arasındaki İlişki: Banka Çalışanları Üzerinde Bir

Araştırma

\section{GIRISŞ}

Psikolojik şiddet (mobbing) ile ilgili bilimsel araștırmaların sayısı hızla artmaktadır. Bunun nedeni şüphesiz psikolojik şiddetin doğurduğu sonuçlar itibari ile toplumsal bir sorun teşkil etme potansiyelidir. Gerek psikolojik şiddet, gerek tükenmişlik sendromu kişinin şahsi bütünlügünü zedelemekle kalmayıp, kurum içi ilişki ve aidiyet duygusunu da tahrip etmektedir.

Psikolojik şiddet algısı, tükenmişlik sendromu ve işten ayrılma niyeti arasındaki ilişkiyi banka çalışanları üzerinde yapılan bir araştırma ile değerlendiren çalışma kapsamında, bankacılık sektöründe karşılaşılan psikolojik şiddete ilişkin algının, tükenmişlik sendromu ve işten ayrılma niyeti ile olan ilişkisi incelenmektedir. Bankacılık sektörü, müşteri memnuniyetinin ve bağlılığının ön planda olduğu dolayısıyla çalışanların müşterileri memnun etmek zorunda oldukları bir hizmet sektörüdür. Bankacılık sektöründe, banka çalışanlarının maruz kaldıklarını düşündükleri psikolojik şiddete ilişkin algıları arttıkça tükenmişliğin duygusal boyutunun da arttığı ve böylece artan duyarsızlıklarının yol açtığ etkilerin işten ayrılma ile ilişkisi ortaya konmuştur. Bu çalışmada; psikolojik şiddet algısı, tükenmişlik sendromu ve işten ayrılma niyeti arasındaki ilişki banka çalışanları üzerinde yapılan bir araştırma ile değerlendirilmiştir. Çalışma; araştırma modelinin tanımlandığı ilk bölüm, verilerin toplanması ve ölçek formlarının açıklandığı ikinci bölüm ve bulguların ortaya konduğu üçüncü bölümün ardından sonuç ve değerlendirme ile tamamlanmaktadır.

\section{YÖNTEM}

Araştırmanın yöntemi; psikolojik şiddet, tükenmişlik sendromu ve işten ayrılma niyeti kavramlarının açıklanarak kavramsal çerçevenin oluşturulması ardından çalışmanın modelinin belirlenmesi ve verilerin toplanması ile ölçek formlarının ortaya konması etrafinda şekillenmektedir.

İşyerinde hedef seçilen kişilerin kişilik, özgüven ve özsaygılarına, mesleki durumlarına, sosyal ilişkilerine, sağlıklarına yönelik sürekli ve acımasız saldırıların sergilendiği bir süreç olan ve "yıldır kaçır" olarak da tanımlanan (Tınaz, Bayram ve Hediye, 2008:11) psikolojik şiddet ya da literatürde s1kça rastlanan haliyle mobbing; rahatsızlık verme ve psikolojik saldırıda bulunma anlamlarını içermektedir (Doğan 2009). Mobbing kavramını ilk kez hayvanlar alemi dışında kullanan kişi İsveçli bilim adamı Peter-Paul Heinemann; çocuklardan oluşan bir grubun yalnız ve daha zayıf bir başka çocuğa karşı fiziki saldırı davranışlarını mobbing olarak tanımlamıştır (Özyer ve Orhan, 2012: 511). Bu kavramı, iş yaşamında ilk kez 1980' li yıllarda kullanan İsveç' de yaşayan Alman asıllı psikolog Heinz Leymann (Leymann, 1996, Taşpınar vd. , 2013:400) mobbingi; “bir veya birkaç kişi tarafından, bir diğer kişiye sistematik, düşmanca ve ahlak dışı bir iletişim yöneltilmesi şeklinde ortaya çıkan bir çeşit psikolojik terör ve çatı̧̧ma aşaması, işyerinde psikolojik şiddetin başlaması, yönetimin devreye girmesi, yanlış yakıştırmalar ve tanımlamalarda bulunulma, işten uzaklaşma aşamalarından oluşan bir süreç olarak tanımlamıştır. Duygusal bir saldırı olan (Göktürk ve Bulut, 2012:56) ve psikolojik terör (Çobanoğlu, 2005, Göktürk ve Bulut, 2012) olarak da 
ifade edilen psikolojik şiddet kavramsal olarak dikey (Tümer, 2013: 14) ve yatay (Yaman, 2009: 27) olmak üzere ikiye ayrılmıştır ve iletişime yönelik (Atalay, 2010: 17), sosyal ilişkilere yönelik (Özler, Atalay ve Şahin, 2008: 6), kişinin itibarına yönelik(Dikmetaş, Top ve Ergin, 2011: 142), yaşam kalitesi ve mesleki duruma yönelik (Aygün, 2012:96), sağlığa yönelik(Temizel, 2013: 209) olmak üzere beş alt grupta toplanmıştır.

Modern çağın sendromları arasında yer alan tükenmişlik kavramı, ilk kez 1961 yılında yayınlanan Greene' nin "Bir Tükenmişlik Olayı (A Burnt-Out Case)" romanında psikolojik açıdan çöküntüye uğramış bir mimarın işini bırakıp Afrika ormanlarına kaçışından bahsetmesiyle gündeme gelmiştir. Romanda mimarın işiyle ilgili hissettiği bitkinlik ve öfke duyguları sonucu idealizmini kaybetmesinden söz edilmektedir (Yıldırım ve İçerli, 2010: 124). Tükenmişlik sendromu, 1974 yılında Freudenberger" in kaleme aldığg makale ile literatüre girmiş; "mesleki bir tehlike", "aşırı yüklenme, yıpranma, başarısız olma" sonucu güç ve enerji kaybı ve karş1lanamayan istekler sonucunda kişinin içsel enerjisinde tükenme durumu olarak tanımlanmıştır (Arı ve Çına Bal, 2008: 132). Cherniss (1980) tükenmişliği aşırı bağlılık duygusu sonucu oluşan aşırı stres ve doyumsuzluk kaynaklı geri çekilme olarak tanımlamıştır (Ok, 2002: 18). Edelwich (1980) ise bu sendromu, hizmet sektörü çalışanlarının çalışma şartlarının bir sonucu olarak idealizm, enerji ve deneyimlerinde bir azalma süreci olarak ifade etmiştir (Cemaloğlu ve Kayabaşı, 2007: 127). Tükenmişlik sendromu; iş hayatı içinde çalışanın fiziksel ve duygusal olarak kendini güçsüz hissetmesi ve çalışma enerjisini kaybetmesi hali olarak da açıklanmaktadır (Filizöz ve Ay, 2011: 230). Tükenmişlik, özellikle kişi işyerinde iyi bir performans gösterdiği halde çabasının karşılığını alamadığını hissettiği durumlarda ortaya çıkmaktadır (Tümkaya, 1996: 28). Tükenmişlik; dinlenme ile geçen bir yorgunluk hali değil, sosyal ilişki kaynaklı bir sendromdur(Sünter, et al. , 2006: 9-14). Tükenmişlik, iş hayatında kendisine büyük hedefler koyan ancak meslek hayatında bunun karşılığını bulamayarak hayal kırıklığına uğrayan, yorulduğunu ve enerjisinin tükendiğini hisseden çalışanlarda daha çok görülmektedir (Cemaloğlu ve Erdemoğlu Şahin, 2007: 467). Tükenmişlik sendromunun çoğu meslek grubunda görülmekle birlikte insanlarla yüz yüze çalış1lan sektörlerde daha çok görüldüğü araştırmalarda tespit edilmiştir (Oğuzberk ve Aydin, 2008: 168).

Maslach Tükenmişlik Envanterini geliştiren Christina Maslach tükenmişlik kavramın1; duygusal tükenme (emotionalexhaustion) (Ar1 ve Çına Bal, 2008: 133), duyarsızlaşma (depersonalization) (Ören ve Türkoğlu, 2006: 2) ve kişisel başarıda düşme (personel accomplishment) (Güllüce ve Kaygın, 2013: 237) olmak üzere üç boyutta incelemiştir (Maslach ve Jackson, 1981, Ardıç ve Polatçı, 2008: 71, Yıldırım vd. , 2014). Sözkonusu incelemede; duygusal tükenme bireylerdeki fiziksel ve duygusal kaynaklardaki tükenmeyi, duyarsızlaşma kişiler arası ilişkileri, onlara karşı tepkisizleşme ya da olumsuz tutumları, düşük kişisel başarı duygusu ise kişinin kendisini olumsuz değerlendirme eğilimini açıklamaktadır (Otacıŏglu, 2008: 104-105). Shirom (2005) tükenmişlik için daha ileri kurumsal açıklamalara ihtiyaç olduğunu belirtmiş; özellikle duygusal tükenme boyutunun temel bileşen 
Haluk Tanrıverdi \& Gelengül Koçaslan \& Nurdan Osmanoğlu Taştan / Psikolojik Şiddet Algısl,

olduğuna vurgulamıştır (Oğuzberk ve Aydın, 2008:168). Tükenmişlik sendromu; şevk ve coşku evresi(Kaçmaz, 2005: 30), durağanlaşma evresi(Üngüren, et al. 2010: 2924), engellenme evresi(Kaçmaz 2005, 30) ve umursamazlık evresi(Üngüren, et al. 2010: 2924) olmak üzere 4 evrede incelenmektedir.

Çalışanların iş koşullarından tatminsiz olmaları durumunda göstermiş oldukları yıkıcı ve aktif eylemler işten ayrılma niyetini ifade etmektedir (Yıldırım vd., 2014). Tett ve Meyer işten ayrılma niyetinin işten ayrılma davranışının en önemli göstergesi olduğunu ifade etmektedirler (Tett ve Meyer, 1993: 259). Çalışma ortamının bozulması da işten ayrılma niyetini etkiler. Rusbelt (1988) işten ayrılma niyetini, çalışma şartlarının olumsuz olması durumunda çalışanların iş doyumunun azalması sonucu gösterdikleri aktif ve yıkıcı bir eylem olarak tanımlamaktadır (Demir ve Tütüncü, 2010: 68). "İșten ayrılma bir bireyin kendi kararı sonucu sosyal sistemden çıkma eğilimidir" (Gaertner 1999, 479). Egan, Yang ve Bartlett (2004) de işten ayrılma eğilimini, çalışanların işi bırakma yönünde istek ve bilinçli arayışlarının sonucu işi bırakma yönündeki kasıtlı ve bilinçli tutum ve davranışları olarak tanımlamıştır (Avcı ve Küçükusta, 2009: 37). Bir çalışanın işten ayrılma niyetinin aktif davranışa dönüşmesi belli bir süreç içinde olur ve bu süreç pek çok faktörden etkilenebilir. Bu faktörler dişsal faktörler ( piyasanın durumu, iş olanakları gibi), örgütsel faktörler (ücret, kurum değerleri, çalışma ortamı, performans sistemi gibi), kişisel faktörler (çalışanın kişilik yapısı, maddi durumu, yaşı, eğitimi gibi) olarak sıralanabilir. Çalışan kişi, işten ayrılma niyetine girdikten sonra, iş arayışı içine girer ve karşısına çıkan iş fırsatlarını değerlendirirken maddi ve manevi kazançlarını ve işten çıkacağı durumdaki maddi ve manevi kayıplarını kıyaslayarak ve bir değerlendirme yaparak karar verir (F. Şahin, 2011: 279). İşten ayrılma niyeti kişinin kendi düşüncesidir ve bu düşünce içine giren çalışanların motivasyonu ve örgüte bağl1lı̆g 1 düşüktür ve kurum içinde bir şeylerden rahatsızdırlar (Kahumuza, 2008: 7).

\section{A.Model}

Psikolojik şiddet iş motivasyonu ve yaratıcıllı̆ı̆ın, işletmenin genelini olumsuz yönde etkileyerek; verimlilikte düşüşe neden olduğu için ekonomik kayıplara yol açmaktadır. Psikolojik şiddet mağduru, mevcut iş ortamından soğuyarak başka iş aramaya başlayabilir (Davenport, Schwardz ve Elliott 2003, $68)$.

Farklı sektörlere yönelik yapılan araştırmalar çalışanlara yapılan psikolojik şiddetin yani mobbingin işten ayrılma niyetini pozitif yönde etkilediğini göstermektedir (Erdirençelebi ve Filizöz, 2016, Quine, 1999, Simons, 2008, Sökmen ve Mete, 2015). Diğer bir deyişle çalışanlar mobbinge maruz kaldıkça işten ayrılma niyeti ortaya çıkmaktadır.

Mete vd. (2015), öğretmenlerin psikolojik şiddete maruz kalma ve işe bağl tükenmişlik algılarının demografik değişkenlere göre farklılık gösterip göstermediğini ve psikolojik şiddete maruz kalma algısı ile işe bağlı tükenmişlik algısı arasındaki ilişkiyi araştırmışlardır. Sözkonusu araştırma sonuçlarına göre; işe bağlı tükenmişlik algısı ile medeni durum, branş, yaş ve kıdem değişkenleri 
arasında ve psikolojik şiddet algısı ile cinsiyet ve yaş değişkenleri arasında anlamlı bir ilişki ortaya çıkmakla birlikte; psikolojik şiddet ile işe bağlı tükenmişlik algıları arasında anlamlı, pozitif ancak zayıf bir ilişki bulunmuş ve psikolojik şiddet algısının tükenmişliği pozitif etkilediği tesbit edilmiştir.

Yıldırım vd. 'nin (2014) Tükenmişlik ile işten ayrılma niyeti arasındaki ilişkiyi belirlemek amacıyla Gaziantep'te faaliyet gösteren bankaların çalışanları üzerinde gerçekleştirdikleri araştırma sonuçları çalışanların tükenmişlik düzeyi ile işten ayrılma niyeti arasında pozitif yönlü bir ilişki olduğunu göstermektedir (Yıldırım vd., 2014). Banka çalışanlarının işten ayrılma niyetleri üzerinde etkili olan faktörleri araştırmaya yönelik bir diğer çalışmada da tükenmişliğin işten ayrılma niyetini anlamlı biçimde etkilediği ortaya konmuştur(Taslak, 2015). Asistan hekimlerin tükenmişlik ve mobbing düzeylerinin incelendiği bir diğer çalışmada psikolojik şiddet, duygusal tükenmişliğin anlamlı bir regresörü olarak ifade edilmiştir (Dikmetaş vd. , 2011). Banka çalışanlarının işten ayrılma niyetleri üzerinde etkili olan faktörleri araştırmaya yönelik bir diğer çalışmada da tükenmişliğin işten ayrılma niyetini anlamlı biçimde etkilediği ortaya konmuştur(Taslak, 2015). Çalışmanın hipotezleri aşağıda sıralanmaktadır:

Hipotez 1: Psikolojik şiddet ile işten ayrlma niyeti arasında pozitif, anlamlı ilişsi vardır.

Hipotez 2: Psikolojik şiddet ile tükenmişlik arasında anlamlı pozitif ilişki vardir. vardır.

Hipotez 3: Tükenmişlik ile işte ayrılma niyeti arasında anlamlı pozitif ilişki vardir.

Hipotez4: Psikolojik şiddet ile tükenmişlik arasında anlaml pozitif ilişki

$\mathrm{Bu}$ çalışmada banka çalışanlarının psikolojik şiddet algısı, tükenmişlik sendromu düzeyleri ve işten ayrılma niyeti değişkenleri olmak üzere üç değişken grubu bulunmaktadır. Psikolojik şiddet algısının tükenmişlik sendromuna ve işten ayrılma niyetine, tükenmişlik sendromunun da işten ayrılma niyetine etkisi olabileceği görüşüne dayanılarak kurulan model Şekil-1 de görülmektedir. Bu üç değişkenin ayrı ayrı faktör analizine tabi tutulması sonucu ortaya çıkan alt boyutları, şekil üzerinde gösterilmiştir. 
Haluk Tanrıverdi \& Gelengül Koçaslan \& Nurdan Osmanoğlu Taştan / Psikolojik Şiddet Algısı,

Şekil.1: Araştırmanın modeli

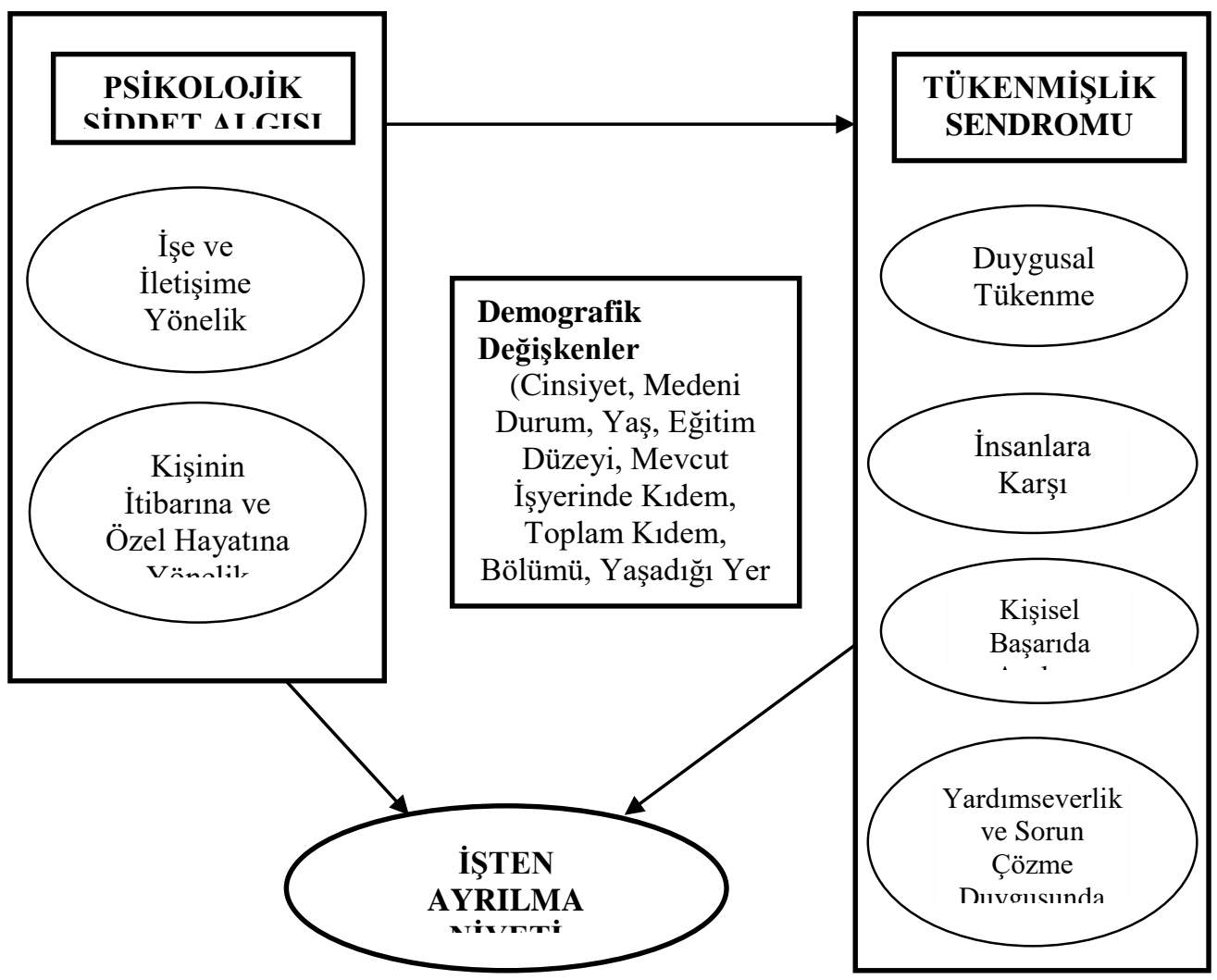

\section{B.Verilerin Toplanması Ve Ölçek Formları}

Araştırma verileri İstanbul ili içerisinde genel merkez ve şubeleri ile birlikte il dışında da Marmara Bölgesi'ndeki şubeleri bulunan 243 özel katılım banka çalışanı tarafından tamamı doldurulmuş 243 anket formlarından elde edilmiştir. Örneklem, katılım bankası çalışanlarını kapsamaktadır. Anket yapılırken ölçek olarak literatürde farklı araştırmalarla geçerliliği ve güvenilirliği test edilmiş ölçekler kullanılmıştır. Anket formu bir önbilgi yazısı ile başlamaktadır. Ankette yer alan ilk sekiz soru cevaplayıcılara ait demografik bilgileri (cinsiyet, medeni durum, yaş, eğitim düzeyi, mevcut işyerinde kıdem, toplam kıdem, görev yaptığı bölüm, yaşadığı yer) elde etmeye yöneliktir. Ankete katılanlardan 64 adedi bilgisayar ortamında e-posta yoluyla, 179 tanesi ise bizzat görüşme yapılarak veriler toplanmıştır. Anket 2014 yılında yapılmış olup, örneklem genelleştirilebilir özellikte bulunamamaktadır. Ankette yer alan diğer ölçekler aşağıda sıralanmaktadır:

Leyman`ın Psikolojik Terör Envanteri (Leymann Inventory of Physchological Terror); 1993 yılında Heinz Leymann tarafından geliştirilen ölçek 
toplam 45 sorudan oluşmaktadır. Bu çalışmada psikolojik şiddet düzeyini ölçmek için Leyman`ın Psikolojik Terör Envanteri kullanılmıştır. Psikolojik şiddet davranışları iletişime yönelik, sosyal ilişkilere yönelik, kişinin itibarına yönelik, yaşam kalitesine ve mesleki durumuna yönelik ve sağlığına yönelik olmak üzere ifade edilen beş alt boyut bu çalışmada 17 soru ile temsil edilmiştir ve beşli Likert ölçeği biçimindedir."Psikolojik şiddet algisl" ölçeğindeki 17 maddenin güvenirliğini hesaplamak için iç tutarlılık katsayısı olan "Cronbach Alpha" hesaplanmıştır. Ölçeğin genel güvenirliği alpha $=0.942$ olarak çok yüksek bulunmuştur. Ölçeğin yapı geçerliliğinin ortaya koymak için açıklayıcı (açımlayıcı) faktör analizi yöntemi uygulanmıştır. Yapılan Barlett testi sonucunda $(\mathrm{p}=0.000<0.05)$ faktör analizine alınan değişkenler arasında ilişkinin olduğu tespit edilmiştir. Yapılan test sonucunda $(\mathrm{KMO}=0.945>0,60)$ örnek büyüklügünün faktör analizi uygulanması için yeterli olduğu tespit edilmiştir. Faktör analizi uygulamasında varimax yöntemi seçilerek faktörler arasındaki ilişkinin yapısının aynı kalması sağlanmıştır. Faktör analizi sonucunda değişkenler toplam açıklanan varyans1 \%59.91 olan 2 faktör altında toplanmıştır. Güvenirliğine ilişkin bulunan alpha ve açıklanan varyans değerine göre "Psikolojik şiddet alglsl" ölçeğinin geçerli ve güvenilir bir araç olduğu anlaşılmıştır.

Ölçeği oluşturan faktörlerin güvenirlik katsayıları ve açıklanan varyans oranlarının yüksek olması ölçeğin güçlü bir faktör yapısına sahip olduğunu göstermiştir. Birinci faktörde yer alan maddeler "İşe ve iletişsime yönelik psikolojik şiddet algısı" olarak ele alınmıştır. "İşe ve iletişime yönelik psikolojik şiddet algısl" faktörünü oluşturan 12 maddenin güvenirliği alpha= 0.934 olarak, açıklanan varyans değeri \%37.691 olarak saptanmıştır. İkinci faktörde yer alan maddeler "Itibara ve özel hayata yönelik psikolojik şiddet algısl" olarak ele alınmıştır. "Itibara ve özel hayata yönelik psikolojik şiddet alglsl" faktörünü oluşturan 5 maddenin güvenirliği alpha $=0.795$ olarak, açılanan varyans değeri \%22.219 olarak saptanmıştır.

Ölçeğe ait oluşan faktör yapısı aşağıda görülmektedir.

Tablo 1. Psikolojik Şiddet Algısı Ölçeği Faktör Yapısı

\begin{tabular}{|c|c|c|c|c|}
\hline \multirow{5}{*}{$\begin{array}{l}\text { İşe ve iletişime } \\
\text { yönelik } \\
\text { psikolojik şiddet } \\
\text { algısı } \\
\text { (Özdeğer=9.005) }\end{array}$} & Madde & $\begin{array}{l}\text { Faktör } \\
\text { Yükü }\end{array}$ & $\begin{array}{l}\text { Açıklanan } \\
\text { Varyans }\end{array}$ & $\begin{array}{l}\text { Cronbach's } \\
\text { Alpha }\end{array}$ \\
\hline & $\begin{array}{l}\text { İşinizi tam ve zamanında yaptığınızda } \\
\text { dahi kasıtlı olarak olumsuz } \\
\text { eleştirildiğiniz oldu mu? }\end{array}$ & 0,823 & 37,691 & 0,934 \\
\hline & $\begin{array}{l}\text { Varlığınızın görmezden gelindiği ya da } \\
\text { fikirlerinizi ifade etmenizin } \\
\text { engellendiği oldu mu? }\end{array}$ & 0,785 & & \\
\hline & $\begin{array}{l}\text { Yaptığınız işler yanlış ve küçümseyici } \\
\text { bir tavırla değerlendirildi mi? }\end{array}$ & 0,750 & & \\
\hline & $\begin{array}{l}\text { Halen çalıştı̆̆ınız kurumda son } 6 \text { ay } \\
\text { veya öncesinden bugüne kendinizi } \\
\text { gösterme olanaklarınız diğer calışanlar }\end{array}$ & 0,738 & & \\
\hline
\end{tabular}


Haluk Tanrıverdi \& Gelengül Koçaslan \& Nurdan Osmanoğlu Taştan / Psikolojik Şiddet Algısı,

\begin{tabular}{|c|c|c|c|c|}
\hline & $\begin{array}{l}\text { tarafindan bilinçli olarak engellendi } \\
\text { mi? }\end{array}$ & & & \\
\hline & $\begin{array}{l}\text { Diğer çalışanların yanında kasıtlı } \\
\text { olarak sizi rencide edici davranışlar } \\
\text { sergilendi mi? }\end{array}$ & 0,731 & & \\
\hline & $\begin{array}{l}\text { Başkalarının hatalarından dolayı sizin } \\
\text { sorumlu tutulduğunuz oldu mu? }\end{array}$ & 0,661 & & \\
\hline & $\begin{array}{l}\text { Size anlamsız kapasitenizin altında } \\
\text { görevler veya yetiştiremeyeceğiniz işler } \\
\text { verildi mi? }\end{array}$ & 0,646 & & \\
\hline & $\begin{array}{l}\text { Çalışma alanınızın sizinle aynı düzeyde } \\
\text { çalışanlara göre daha kısıtlı veya } \\
\text { dezavantajlı olarak tahsis edildiğini } \\
\text { hissettiniz mi? }\end{array}$ & 0,636 & & \\
\hline & Sözlü ya da yazılı tehditler aldınız mı? & 0,633 & & \\
\hline & $\begin{array}{l}\text { Yaşadığınız psikolojik baskılar nedeni } \\
\text { ile sağlığınız ya da uyku düzeniniz } \\
\text { bozuldu mu? }\end{array}$ & 0,615 & & \\
\hline & $\begin{array}{l}\text { Üst yönetime karşı, haketmediğiniz } \\
\text { halde, üstleriniz ya da diğer çalışanlar } \\
\text { tarafindan olumsuz lanse edildiğiniz } \\
\text { oldu mu? }\end{array}$ & 0,613 & & \\
\hline & $\begin{array}{l}\text { İşyerinde hissettiğiniz psikolojik baskı } \\
\text { nedeniyle işe gitmek istemediğiniz } \\
\text { günler oldu mu? }\end{array}$ & 0,562 & & \\
\hline $\begin{array}{l}\text { İtibara ve özel } \\
\text { hayata yönelik } \\
\text { psikolojik şiddet } \\
\text { algısı } \\
\text { (Özdeğer=1.180) }\end{array}$ & $\begin{array}{l}\text { İşyerinde Sözlü Ya Da Fiili Cinsel } \\
\text { Tacize Maruz Kaldınız Mı? } \\
\text { İmalı Bakışlara, Olumsuz Mimiklere } \\
\text { Maruz Kaldınız Mı? } \\
\text { Özel Yaşamınızla İlgili Hakaret } \\
\text { Boyutuna Varan Yorumlar Yapıldı mı? } \\
\text { İşyerinde Dışlandığınız Ya Da Kasıtlı } \\
\text { Olarak Yalnız Bırakıldığınız Oldu Mu? } \\
\text { Hakkınızda Asılsız Dedikodu Ve } \\
\text { İftiralar üretildi mi? }\end{array}$ & $\begin{array}{l}0,749 \\
0,707 \\
0,616 \\
0,607 \\
0,551\end{array}$ & 22,219 & 0,795 \\
\hline
\end{tabular}

Maslach ve Jackson Tükenmişlik Ölçeği (1981); Çam (1991) ve Ergin (1993, 1996) tarafından geçerlilik ve güvenilirlik çalışması yapılan ölçek 22 sorudan oluşmaktadır. Duygusal tükenme, duyarsızlaşma ve kişisel başarıda düşme olarak üç alt boyuttan oluşmaktadır. "Tükenmişlik" ölçeğindeki 22 maddenin güvenirliğini hesaplamak için iç tutarlılık katsayısı olan "Cronbach Alpha" hesaplanmıştır. Ölçeğin genel güvenirliği alpha $=0.915$ olarak çok yüksek bulunmuştur. Ölçeğin yapı geçerliliğinin ortaya koymak için açılayıcı (açımlayıcı) 
faktör analizi yöntemi uygulanmıştır. Yapılan Barlett testi sonucunda $(p=0.000<0.05)$ faktör analizine alınan değişkenler arasında ilişkinin olduğu tespit edilmiştir. Yapılan test sonucunda $(\mathrm{KMO}=0.928>0,60)$ örnek büyüklüğünün faktör analizi uygulanması için yeterli olduğu tespit edilmiştir. Faktör analizi uygulamasında varimax yöntemi seçilerek faktörler arasındaki ilişkinin yapısının aynı kalması sağlanmıştır. Faktör analizi sonucunda değişkenler toplam açıklanan varyans $\% 58.506$ olan 4 faktör altında toplanmıştır. Güvenirliğine ilişkin bulunan alpha ve açıklanan varyans değerine göre "Tükenmişlik" ölçeğinin geçerli ve güvenilir bir araç olduğu anlaşılmıştır.

Birinci faktörde yer alan maddeler "Duygusal tükenme" olarak ele alınmıştır. "Duygusal tükenme” faktörünü oluşturan 9 maddenin güvenirliği alpha $=0.893$ olarak, açıklanan varyans değeri \% 23.179 olarak saptanmıştır. İkinci faktörde yer alan maddeler "Ínsanlara karşı duyarsızlık" olarak ele alınmıştır. "Insanlara karşı duyarsızlık" faktörünü oluşturan 7 maddenin güvenirliği alpha= 0.815 olarak, açıklanan varyans değeri \% 17.814 olarak saptanmıştır. Üçüncü faktörde yer alan maddeler "Kişisel başarıda azalma" olarak ele alınmıştır. "Kişisel başarıda azalma" faktörünü oluşturan 3 maddenin güvenirliği alpha= 0.632 olarak, açıklanan varyans değeri \% 9.179 olarak saptanmıştır. Dördüncü faktörde yer alan maddeler "Yardımseverlik ve sorun çözme duygusunda azalma" olarak ele alınmıştır. "Yardımseverlik ve sorun çözme duygusunda azalma" faktörünü oluşturan 3 maddenin güvenirliği alpha= 0.586 olarak, zayıf düzeyde güvenilir değere sahip olup, açıklanan varyans değeri \% 8.334 olarak saptanmıştır. Ölçeğe ait oluşan faktör yapısı aşağıda görülmektedir.

Tablo 2. Tükenmişlik Ölçeği Faktör Yapısı

\begin{tabular}{|c|c|c|c|c|}
\hline Boyut & Madde & $\begin{array}{l}\text { Faktör } \\
\text { Yükü }\end{array}$ & $\begin{array}{l}\text { Açıklanan } \\
\text { Varyans }\end{array}$ & $\begin{array}{l}\text { Cronbach's } \\
\text { Alpha }\end{array}$ \\
\hline \multirow[t]{9}{*}{$\begin{array}{l}\text { Duygusal } \\
\text { tükenme } \\
(\text { Özdeğer=8.355) }\end{array}$} & $\begin{array}{l}\text { Sabah Kalkıp Yeni Bir İş Gününe Başlamak } \\
\text { Zorunda Olduğum Zaman, Yorgunluk } \\
\text { Hissediyorum. }\end{array}$ & 0,822 & 23,179 & 0,893 \\
\hline & İşimden Dolayı Tükendiğimi Hissediyorum. & 0,769 & & \\
\hline & İşimden Soğuduğumu Hissediyorum. & 0,757 & & \\
\hline & $\begin{array}{l}\text { İş Günü Sonunda Kendimi Tükenmiş } \\
\text { Hissediyorum. }\end{array}$ & 0,752 & & \\
\hline & İşimin Beni Kısıtladığını Düşünüyorum. & 0,729 & & \\
\hline & Sabrımın Tükendiğini Hissediyorum. & 0,645 & & \\
\hline & Kendimi Çok Enerjik Hissediyorum. & 0,644 & & \\
\hline & $\begin{array}{l}\text { Bu İşin, Beni Duygusal Olarak Körelttiğinden } \\
\text { Endișe Ediyorum. }\end{array}$ & 0,544 & & \\
\hline & $\begin{array}{l}\text { İşyerinde Çok Yoğun Çalıştığımı } \\
\text { Düşünüyorum. }\end{array}$ & 0,323 & & \\
\hline \multirow{3}{*}{$\begin{array}{l}\text { İnsanlara karşı } \\
\text { duyarsızlık } \\
(\text { Özdeğer=2.169) }\end{array}$} & $\begin{array}{l}\text { İnsanlarla Doğrudan Birlikte Çalışmak Bende } \\
\text { Çok Fazla Stres Yaratıyor. }\end{array}$ & 0,748 & 17,814 & 0,815 \\
\hline & $\begin{array}{l}\text { Hizmet Verdiğim Bazı Kişilere Karşı Soğuk } \\
\text { Ve İlgisiz Davrandığımı Hissediyorum. }\end{array}$ & 0,645 & & \\
\hline & $\begin{array}{l}\text { Gün Boyu İnsanlarla Birlikte Çalışmak Beni } \\
\text { Gerçekten Geriyor. }\end{array}$ & 0,645 & & \\
\hline
\end{tabular}


Haluk Tanrıverdi \& Gelengül Koçaslan \& Nurdan Osmanoğlu Taştan / Psikolojik Şiddet Algısı,

Tükenmişlik Sendromu Ve İşten Ayrılma Niyeti Arasındaki İlişki: Banka Çalışanları Üzerinde Bir

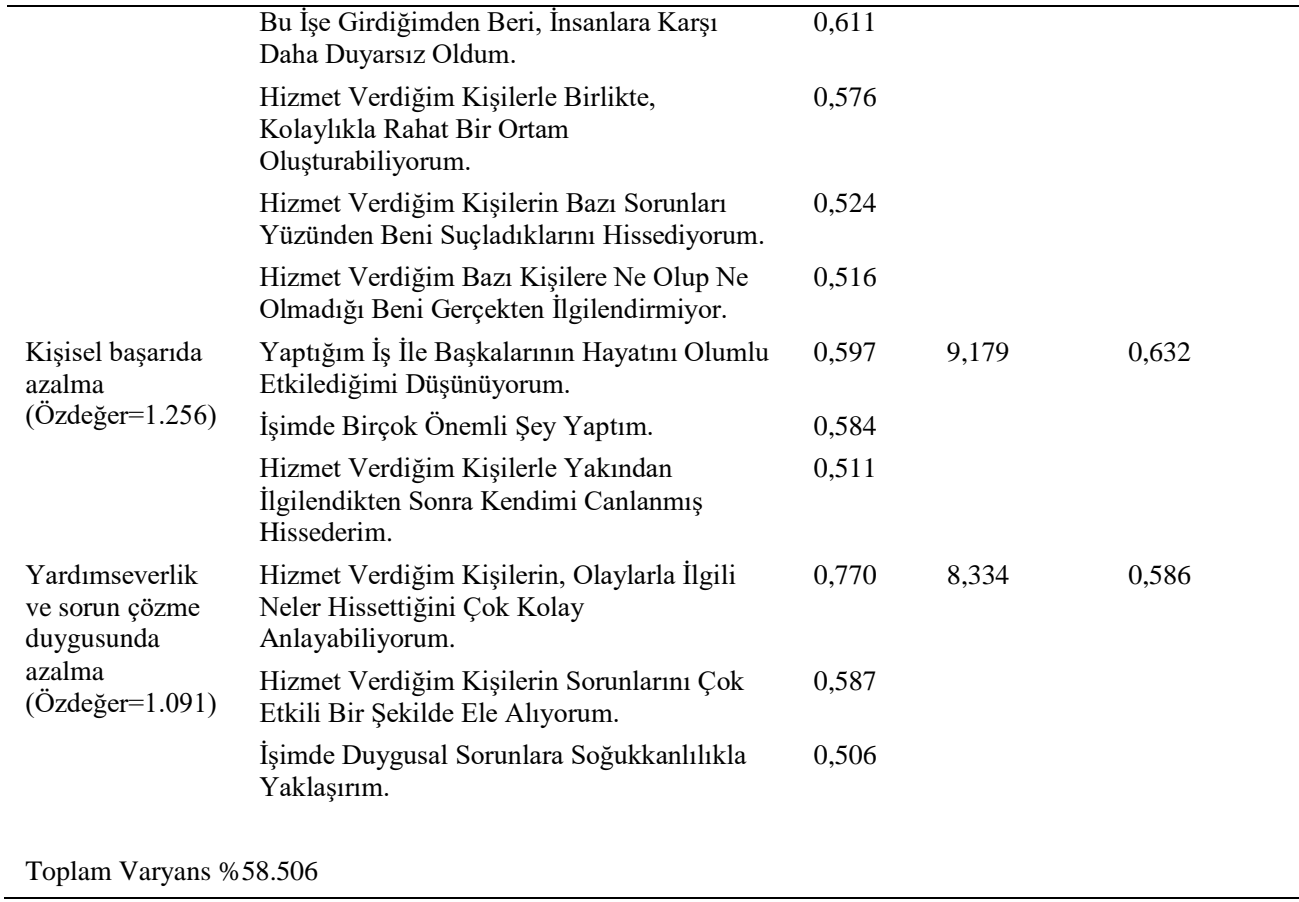

İşten Ayrılma Niyeti Ölçeği; Bilgi işçilerinin işten ayrılma niyetlerini ölçmek amacıyla Camman ve arkadaşları tarafından geliştirilen 3 ifadeden oluşan ölçektir. Camman, Fichman, JenkinsandKlesh'in (1979) "The Organizational Assessment Questionnaire" adlı çalışmasında yer almaktadır. "Iş̦ten Ayrılma Niyeti" "ölçeğindeki 3 maddenin güvenirliğini hesaplamak için iç tutarlılık katsayısı olan "Cronbach Alpha" hesaplanmıştır. Ölçeğin genel güvenirliği alpha=0.931 olarak çok yüksek bulunmuştur. Ölçeğin yapı geçerliliğinin ortaya koymak için açıklayıcı(açımlayıcı) faktör analizi yöntemi uygulanmıştır.Yapılan Barlett testi sonucunda $(\mathrm{p}=0.000<0.05)$ faktör analizine alınan değişkenler arasında ilişkinin olduğu tespit edilmiştir. Test sonucunda $(\mathrm{KMO}=0.739>0,60)$ örnek büyüklügünün faktör analizi uygulanması için yeterli olduğu tespit edilmiştir. Faktör analizi uygulamasında varimax yöntemi seçilerek faktörler arasındaki ilişkinin yapısının aynı kalması sağlanmıştır. Faktör analizi sonucunda değişkenler toplam açıklanan varyans1 \%88,320 olan tek faktör altında toplanmıştır. Güvenirliğine ilişkin bulunan alpha ve açılanan varyans değerine göre İşten ayrılma niyeti ölçeğinin geçerli ve güvenilir bir araç olduğu anlaşılmıştır. Ölçeğe ait oluşan faktör yapısı aşağıda görülmektedir. 
Tablo 3. İșten Ayrılma Niyeti Ölçeği Faktör Yapısı

\begin{tabular}{|l|c|}
\hline & Faktör Yükü \\
\hline Şuan yaptığım işten ayrılmak istiyorum. & $\mathbf{0 , 9 5 8}$ \\
\hline Büyük bir ihtimalle önümüzdeki yıl başka bir iş bakacağım. & $\mathbf{0 , 7 2 3}$ \\
\hline Bazen işimden ayrılmayı düşünüyorum. & $\mathbf{0 , 7 0 5}$ \\
\hline
\end{tabular}

Araştırmada elde edilen veriler SPSS (Statistical PackageforSocialSciences) for Windows 21.0 programı kullanılarak analiz edilmiştir. Verileri değerlendirilirken tanımlayıcı istatistiksel metotları (sayı, yüzde, ortalama, standart sapma) kullanılmıştır. Niceliksel verilerin karşılaştırılmasında iki grup arasındaki farkı t-testi, ikiden fazla grup durumunda parametrelerin gruplararası karşılaştırmalarında Tek yönlü (Oneway) Anovave farklılığa neden olan grubun tespitinde Tukey Post Hoc testleri kullanılmıştır.

\section{II.BULGULAR}

Banka çalışanları cinsiyet değişkenine göre $187(\% 77,0)$ erkek, $56(\% 23,0)$ kadın; medeni hal değişkenine göre $150(\% 61,7)$ evli, $93(\% 38,3)$ bekar; yaş değişkenine göre $141(\% 58,0) 30$ yaş ve altı, $102(\% 42,0) 31$ yaş ve üzeri; eğitim düzeyi değişkenine göre $11(\% 4,5)$ lise-açıköğretim-önlisans, $148(\% 60,9)$ lisans, $84(\% 34,6)$ yüksek lisans ve üstü olarak dağılmaktadır. Araştırmaya katılanların cinsiyet dağılımı açısından erkek çalışanların fazlalığı katılım bankacılığı açısından ana kitle örneklemi içinde değerlendirilebilir.

Araştırma bulgularında ortaya çıkan işe bağlı tükenmişlik ve psikolojik şiddet alg1 düzeyinin düşüklüğü; tükenmişlik genel ve alt boyutları bekar kadınlarda 30 ve üstünde ve eğitimi lisans olanlarda ortaya çıkan yüksek düzey; psikolojik şiddet ile işe bağlı tükenmişlik düzeyi arasındaki anlamlı pozitif ilişkinin varlığı, psikolojik şiddet algısının tükenmişlik düzeyi üzerinde etkisine ilişkin sonuçlar Mete vd. (2005) yaptığı çalışmayla benzerlik göstermektedir.Çalışmada ortaya çıkan demografik değişkenlerle işten ayrılma niyeti cinsiyete, çalışma süresine, bölüme göre anlamlı farkın oluşması ve demografik değişkenlerle işten ayrılma niyeti ve tükenmişlik düzeyi arasında istatistiki açıdan anlamlı ilişki varlığına ilişkin sonuçlar Yıldırım vd (2014) yapığı çalışmayla uyumludur.Farklı sektörlere yönelik olarak Erdirençelebi ve Filizöz (2016), Quine (1999), Simons (2008), Sökmen ve Mete (2015)'nin yaptıkları araştırmalarda, çalışanlara yapılan psikolojik şiddetin yani mobbingin işten ayrılma niyetini pozitif yönde etkilediği, diğer bir deyişle çalışanlar mobbinge maruz kaldıkça işten ayrılma niyeti belirmekte olduğu sonuçları çalışmamızla paralellik göstermektedir. Elde edilen bulgular Yıldırım, Taslak, ve Dikmetaş'ın belirttiği psikolojik şiddet algısı işten ayrılma niyeti ve tükenmişlik arasında anlamlı ilişkileri içeren bulgularla da örtüşmektedir. 
Haluk Tanrıverdi \& Gelengül Koçaslan \& Nurdan Osmanoğlu Taştan / Psikolojik Şiddet Algısı, Tükenmişlik Sendromu Ve İşten Ayrılma Niyeti Arasındaki İlişski: Banka Çalışanları Üzerinde Bir Araştırma

Tablo. 4:Araştırmaya katılan banka çalışanlarının psikolojik şiddet algısı ile tükenmişlik düzeyleri arasındaki ilişkinin korelasyon analizi ile incelenmesi

\begin{tabular}{|c|c|c|c|c|c|c|}
\hline & & $\begin{array}{l}\text { Duygusal } \\
\text { Tükenme }\end{array}$ & $\begin{array}{l}\text { İnsanlara } \\
\text { Karş1 } \\
\text { Duyarsızlık }\end{array}$ & $\begin{array}{l}\text { Kişisel } \\
\text { Başarıda } \\
\text { Azalma }\end{array}$ & $\begin{array}{l}\text { Yardımseverlik } \\
\text { Ve Sorun } \\
\text { Çözme } \\
\text { Duygusunda } \\
\text { Azalma }\end{array}$ & $\begin{array}{l}\text { Genel } \\
\text { Tükenmişlik }\end{array}$ \\
\hline İşe ve İletişime & $\mathrm{R}$ & $0,626 * *$ & $0,387 * *$ & $0,211 * *$ & $0,180 * *$ & $0,537 * *$ \\
\hline $\begin{array}{l}\text { Yönelik Psikolojik } \\
\text { Şiddet Algısı }\end{array}$ & $\mathrm{P}$ & 0,000 & 0,000 & 0,001 & 0,005 & 0,000 \\
\hline İtibara ve Özel & $\mathrm{R}$ & $0,518 * *$ & $0,379 * *$ & $0,222 * *$ & $0,201 * *$ & $0,481 * *$ \\
\hline $\begin{array}{c}\text { Hayata Yönelik } \\
\text { Psikolojik Şiddet } \\
\text { Algısı }\end{array}$ & $\mathrm{P}$ & 0,000 & 0,000 & 0,000 & 0,002 & 0,000 \\
\hline $\begin{array}{l}\text { Genel Psikolojik } \\
\text { Şiddet Algisi }\end{array}$ & $\begin{array}{l}\mathrm{R} \\
\mathrm{P}\end{array}$ & $\begin{array}{l}0,626 * * \\
0,000\end{array}$ & $\begin{array}{l}0,402 * * \\
0,000\end{array}$ & $\begin{array}{l}0,223 * * \\
0,000\end{array}$ & $\begin{array}{l}0,193 * * \\
0,002\end{array}$ & $\begin{array}{l}0,546 * * \\
0,000\end{array}$ \\
\hline
\end{tabular}

Genel psikolojik şiddet algısı ile genel tükenmişlik arasında istatistiksel açıdan anlamlı ilişki bulunmuştur $(\mathrm{r}=0.546 ; \mathrm{p}=0,000<0.05)$. Buna göre genel psikolojik şiddet algısı arttıkça genel tükenmişlik artmaktadır. Psikolojik şiddet algısı alt boyutları ile tükenmişlik alt boyutları arasında da pozitif anlamlı ilişkiler bulunmuştur.

Tablo. 5:Araştırmaya Katılan Banka Çalışanlarının Psikolojik Şiddet Algısı ile İşten Ayrılma Niyeti Arasındaki İlişkinin Korelasyon Analizi ile İncelenmesi

\begin{tabular}{|c|c|c|}
\hline & & $\begin{array}{l}\text { İşten } \\
\text { Ayrılma } \\
\text { Niyeti }\end{array}$ \\
\hline İşe ve İletişime Yönelik Psikolojik Şiddet Algısı & $\begin{array}{l}R \\
P\end{array}$ & $0,538 * *$ \\
\hline İtibara ve Özel Hayata Yönelik Psikolojik Şiddet Algısı & $\begin{array}{l}\mathrm{R} \\
\mathrm{P}\end{array}$ & $\begin{array}{l}0,456^{* *} \\
0,000\end{array}$ \\
\hline Genel Psikolojik Şiddet Algısı & $\begin{array}{l}\mathrm{R} \\
\mathrm{P}\end{array}$ & $\begin{array}{l}0,541 \text { ** } \\
0,000\end{array}$ \\
\hline
\end{tabular}

Genel psikolojik şiddet algısı ile işten ayrılma niyeti arasında istatistiksel açıdan anlamlı ilişki bulunmuştur $(r=0.541 ; p=0,000<0.05)$. Buna göre genel psikolojik şiddet algısı arttıkça işten ayrılma niyeti artmaktadır. Psikolojik şiddet algısı alt boyutları ile işten ayrılma niyeti arasında da pozitif anlamlı ilişkiler bulunmuştur. 
Tablo. 6:Araştırmaya Katılan Banka Çalışanlarının Tükenmişlik Düzeyleri İle İşten Ayrılma Niyeti Arasındaki İlişkinin Korelasyon Analizi İle İncelenmesi

\begin{tabular}{lll}
\hline & İşten \\
& Ayrilma \\
\hline Duygusal Tükenme & Niyeti \\
İnsanlara Karşı Duyarsızlık & $\mathrm{p}$ & $0,693^{* *}$ \\
& $\mathrm{p}$ & 0,000 \\
Kişisel Başarıda Azalma & $\mathrm{r}$ & $0,543^{* *}$ \\
& $\mathrm{p}$ & 0,000 \\
Yardımseverlik ve Sorun Çözme Duygusunda Azalma & $\mathrm{r}$ & $0,331^{* *}$ \\
& $\mathrm{p}$ & 0,000 \\
Genel Tükenmişlik & $\mathrm{r}$ & $0,237^{* *}$ \\
& $\mathrm{p}$ & 0,000 \\
& $\mathrm{r}$ & $0,657^{* *}$ \\
& $\mathrm{p}$ & 0,000 \\
\hline
\end{tabular}

Genel tükenmişlik ile işten ayrılma niyeti arasında istatistiksel açıdan anlamlı ilişki bulunmuştur $(\mathrm{r}=0.657 ; \mathrm{p}=0,000<0.05)$. Buna göre genel tükenmişlik arttıkça işten ayrılma niyeti artmaktadır. Ayrıca tükenmişlik alt boyutları ile işten ayrılma niyeti arasındada pozitif yönde anlamlı ilişkiler bulunmuştur.

Duygusal tükenme düzeyinin belirleyicisi olarak işe ve iletişime yönelik psikolojik şiddet algısı, itibara ve özel hayata yönelik psikolojik şiddet algısı değişkenleri ile ilişkisinin (açıklayıcılık gücünün) güçlü olduğu görülmüştür $\left(\mathrm{R}^{2}=0,389\right)$. Banka çalışanlarının işe ve iletişime yönelik psikolojik şiddet algısı düzeyi duygusal tükenme düzeyini arttırmaktadır $(\beta=0,549)$. Banka çalışanlarının itibara ve özel hayata yönelik psikolojik şiddet algısı düzeyi duygusal tükenme düzeyini etkilememektedir $(\mathrm{p}=0.311>0.05)$.

İnsanlara karşı duyarsızlık düzeyinin belirleyicisi olarak işe ve iletişime yönelik psikolojik şiddet algısı, itibara ve özel hayata yönelik psikolojik şiddet algısı değişkenleri ile ilişkisinin (açıklayıcılık gücünün) zayıf olduğu görülmüştür $\left(\mathrm{R}^{2}=0,158\right)$. Banka çalışanlarının işe ve iletişime yönelik psikolojik şiddet algısı düzeyi insanlara karşı duyarsızlık düzeyini arttırmaktadır $(\beta=0,198)$. Banka çalışanlarının itibara ve özel hayata yönelik psikolojik şiddet algısı düzeyi insanlara karşı duyarsızlık düzeyini arttırmaktadır $(\beta=0,225)$.

Kişisel başarıda azalma düzeyinin belirleyicisi olarak itibara ve özel hayata yönelik psikolojik şiddet algısı değişkenleri ile ilişkisinin (açıklayıcılık gücünün) zayıf olduğu görülmüştür $\left(\mathrm{R}^{2}=0,045\right)$. Banka çalışanlarının itibara ve özel hayata yönelik psikolojik şiddet algısı düzeyi kişisel başarıda azalma düzeyini arttırmaktadir $(\beta=0,258)$.

Yardımseverlik ve sorun çözme duygusunda azalma düzeyinin belirleyicisi olarak itibara ve özel hayata yönelik psikolojik şiddet algısı değişkenleri ile ilişkisinin (açıklayıcılık gücünün) zayıf olduğu görülmüştür $\left(\mathrm{R}^{2}=0,037\right)$. Banka çalışanlarının itibara ve özel hayata yönelik psikolojik şiddet algısı düzeyi yardımseverlik ve sorun çözme duygusunda azalma düzeyini arttırmaktadır $(\beta=0,219)$.

Genel tükenmişlik düzeyinin belirleyicisi olarak işe ve iletişime yönelik psikolojik şiddet algısı, itibara ve özel hayata yönelik psikolojik şiddet algısı değişkenleri ile ilişkisinin (açıklayıcılık gücünün) güçlü olduğu 
Haluk Tanrıverdi \& Gelengül Koçaslan \& Nurdan Osmanoğlu Taştan / Psikolojik Şiddet Algısl,

görülmüştür $\left(\mathrm{R}^{2}=0,293\right)$. Banka çalışanlarının işe ve iletişime yönelik psikolojik şiddet algısı düzeyi genel tükenmişlik düzeyini arttırmaktadır $(\beta=0,306)$. Banka çalışanlarının itibara ve özel hayata yönelik psikolojik şiddet algısı düzeyi genel tükenmişlik düzeyini etkilememektedir ( $\mathrm{p}=0.062>0.05)$.

Tablo.7:Genel Psikolojik Şiddet Algısı Düzeyinin Genel Tükenmişlik Üzerine Etkisi

\begin{tabular}{|c|c|c|c|c|c|c|c|}
\hline Bağımlı Değişken & $\begin{array}{l}\text { Bağımsız } \\
\text { Değisken }\end{array}$ & $\beta$ & $\mathrm{T}$ & $P$ & $\bar{F}$ & $\begin{array}{l}\text { Model } \\
\text { (p) }\end{array}$ & $\mathrm{R}^{2}$ \\
\hline Genel Tükenmişlik & $\begin{array}{l}\text { Sabit } \\
\text { Genel } \\
\text { Psikolojik } \\
\text { Şiddet } \\
\text { Algisı }\end{array}$ & $\begin{array}{l}1,481 \\
0,458\end{array}$ & $\begin{array}{l}17,926 \\
10,130\end{array}$ & $\begin{array}{l}0,000 \\
0,000\end{array}$ & 102,624 & 0,000 & 0,296 \\
\hline
\end{tabular}

Genel psikolojik şiddet algısı ile genel tükenmişlik arasındaki ilişki belirlemek üzere yapılan regresyon analizi istatistiksel olarak anlamlı bulunmuştur $(\mathrm{F}=102,624 ; \mathrm{p}=0,000<0.05)$. Genel tükenmişlik düzeyinin belirleyicisi olarak genel psikolojik şiddet algısı değişkenleri ile ilişkisinin(açıklayıcılık gücünün) güçlü olduğu görülmüştür $\left(\mathrm{R}^{2}=0,296\right)$. Banka çalışanlarının genel psikolojik şiddet algısı düzeyi genel tükenmişlik düzeyini arttırmaktadır $(\beta=0,458)$.

İşten ayrılma niyeti düzeyinin belirleyicisi olarak işe ve iletişime yönelik psikolojik şiddet algısı, itibara ve özel hayata yönelik psikolojik şiddet algısı değişkenleri ile ilişsisinin (açıklayıcılık gücünün) güçlü olduğu görülmüştür $\left(\mathrm{R}^{2}=0,288\right)$. Banka çalışanlarının işe ve iletişime yönelik psikolojik şiddet algısı düzeyi işten ayrılma niyeti düzeyini arttırmaktadır $(\beta=0,643)$. Banka çalışanlarının itibara ve özel hayata yönelik psikolojik şiddet algısı düzeyi işten ayrılma niyeti düzeyini etkilememektedir $(\mathrm{p}=0.269>0.05)$.

Tablo.8:Genel Psikolojik Şiddet Algısı Düzeyinin İşten Ayrılma Niyeti Üzerine

\begin{tabular}{llllllll}
\multicolumn{9}{c}{ Etkisi } & & & & \\
\hline $\begin{array}{l}\text { Bağımlı } \\
\text { Değişken }\end{array}$ & Bağımsız Değişken & $\beta$ & $\mathrm{T}$ & $\mathrm{P}$ & $\mathrm{F}$ & $\begin{array}{l}\text { Model } \\
(\mathrm{p})\end{array}$ & $\mathrm{R}^{2}$ \\
\hline İşten Ayrılma & Sabit & & & & & & \\
Niyeti & Genel Psikolojik & 0,830 & 4,068 & 0,000 & 99,864 & 0,000 & 0,290 \\
& Şiddet Algısı & 9,993 & 0,000 & & & \\
\hline
\end{tabular}

Genel psikolojik şiddet algısı ile işten ayrılma niyeti arasındaki ilişki belirlemek üzere yapılan regresyon analizi istatistiksel olarak anlamlı bulunmuştur $(\mathrm{F}=99,864 ; \mathrm{p}=0,000<0.05)$. İşten ayrılma niyeti düzeyinin belirleyicisi olarak genel psikolojik şiddet algısı değişkenleri ile ilişkisinin (açıklayıcılık gücünün) güçlü olduğu görülmüştür $\left(\mathrm{R}^{2}=0,290\right)$. Banka çalışanlarının genel psikolojik şiddet algısı düzeyi ișten ayrılma niyeti düzeyini arttırmaktadır $(\beta=0,847)$.

İşten ayrılma niyeti düzeyinin belirleyicisi olarak duygusal tükenme, insanlara karşı duyarsızlık, kişisel başarıda azalma, yardımseverlik ve sorun çözme duygusunda azalma değişkenleri ile ilişkisinin (açıklayıcılık gücünün) çok güçlü olduğu görülmüştür $\left(\mathrm{R}^{2}=0,476\right)$. Banka çalışanlarının duygusal tükenme düzeyi işten ayrılma niyeti düzeyini arttırmaktadır $(\beta=0,891)$. Banka çalışanlarının 
insanlara karşı duyarsızlık düzeyi işten ayrılma niyeti düzeyini etkilememektedir $(\mathrm{p}=0.183>0.05)$. Banka çalışanlarının kişisel başarıda azalma düzeyi işten ayrılma niyeti düzeyini etkilememektedir $(\mathrm{p}=0.787>0.05)$. Banka çalışanlarının yardımseverlik ve sorun çözme duygusunda azalma düzeyi işten ayrılma niyeti düzeyini etkilememektedir $(\mathrm{p}=0.806>0.05)$.

Tablo. 9:Genel tükenmişlik düzeyinin işten ayrılma niyeti üzerine etkisi

$\begin{array}{lllllllll}\text { Bağımlı Değişken } & \begin{array}{l}\text { Bağımsız } \\ \text { Değişken }\end{array} & B & T & p & F & \begin{array}{l}\text { Model } \\ (\mathrm{p})\end{array} & \mathrm{R}^{2} \\ \text { İşten Ayrılma Niyeti } & \text { Sabit } & - & -3,340 & 0,001 & 183,237 & 0,000 & 0,430 \\ & \text { Genel } & 0,706 & & & & & \\ & \text { Tükenmişlik } & 1,228 & 13,537 & 0,000 & & & \\ & & & & & & \end{array}$

Genel tükenmişlik ile işten ayrılma niyeti arasındaki ilişki belirlemek üzere yapılan regresyon analizi istatistiksel olarak anlamlı bulunmuştur $(\mathrm{F}=183,237$; $\mathrm{p}=0,000<0.05$ ). İşten ayrılma niyeti düzeyinin belirleyicisi olarak genel tükenmişlik değişkenleri ile ilişkisinin (açıklayıcılık gücünün) çok güçlü olduğu görülmüştür $\left(\mathrm{R}^{2}=0,430\right)$. Banka çalışanlarının genel tükenmişlik düzeyi işten ayrılma niyeti düzeyini arttırmaktadır $(\beta=1,228)$.

\section{SONUÇ}

Araştırmaya katılan banka çalışanlarının psikolojik şiddet algısı düzeylerinin ortalamaları incelenmiş; "işe ve iletişime yönelik psikolojik şiddet algısı" düzeyi ortalamasının zayıf $(1,821 \pm 0,782)$; "itibara ve özel hayata yönelik psikolojik şiddet algısı" düzeyi ortalamasının çok zayıf $(1,390 \pm 0,576)$; "genel psikolojik şiddet algısı" düzeyi ortalamasının çok zayıf $(1,694 \pm 0,692)$ düzeyde tespit edilmiştir. Araştırmaya katılan banka çalışanlarının tükenmişlik düzeylerinin ortalamaları incelenmiş; "duygusal tükenme " düzeyi ortalamasının zayıf $(2,502 \pm$ 0,763); "insanlara karşı duyarsızlık" düzeyi ortalamasının zayıf $(2,029 \pm 0,660)$; "kişisel başarıda azalma" düzeyi ortalamasının zayıf $(2,152 \pm 0,668)$; "yardımseverlik ve sorun çözme duygusunda azalma" düzeyi ortalamasının zayıf $(2,151 \pm 0,626)$; "genel tükenmişlik" düzeyi ortalamasının zayıf $(2,256 \pm 0,579)$ düzeyde tespit edilmiştir. Araştırmaya katılan banka çalışanlarının işten ayrılma niyeti düzeyi ortalaması zayıf $(2,065 \pm 1,082)$ düzeyde tespit edilmiştir. Psikolojik şiddet algisı düzeylerinin, iş, işyerinde iletişim, itibar ve özel hayata yönelik psikolojik yönüyle düşük düzeyde olması, tükenmişlik düzeyinin zayıf düzeyde bulunması ve işten ayrılma niyetinin zayıf düzeyde gerçekleşmesi kişi, iş, iş yaşamı açısından olumlu olarak değerlendirilebilir.

Banka çalışanlarının çalışma ortamlarında maruz kaldıklarını düşündükleri psikolojik şiddete ilişkin algıları arttıkça tükenmişliğin duygusal boyutu da artmaktadır. Başka bir deyişle, banka çalışanlarının iş yerinde karşılaştıkları psikolojik şiddet düzeyi yüksekliği ile genel olarak tükenmişlik sendromu arasında ilişki bulunmaktadır. Benzer şekilde, banka çalışanlarının çalışma ortamlarında maruz kaldıklarını düşündükleri psikolojik şiddete ilişkin algıları ile işten ayrılma 
Haluk Tanrıverdi \& Gelengül Koçaslan \& Nurdan Osmanoğlu Taştan / Psikolojik Şiddet Algısl, Tükenmişlik Sendromu Ve İșten Ayrılma Niyeti Arasındaki İlişki: Banka Çalışanları Üzerinde Bir

Araştırma

niyeti arasındaki ilişki de psikolojik şiddete uğradığını düşünen çalışanların bireysel mutlulukları için ve kariyer hedeflerini gerçekleştirmek için mevcut işlerinden ayrılma niyetinin ortaya çıkması şeklinde karşımıza çıkmaktadır. Araştırmadan elde edilen sonuçlara göre banka çalışanlarının genel tükenmişlik düzeyleri ve genel psikolojik şiddet algıları, işten ayrılma niyetlerini etkilemektedir. Banka çalışanlarının genel psikolojik şiddet algılarının ise genel tükenmişlik düzeylerini etkilediği görülmektedir.

\section{KAYNAKÇA}

Ardıç, K. ve Polatçı, S. (2008). Tükenmişlik Sendromu: Akademisyenler Üzerinde Bir Uygulama. Gazi Üniversitesi İktisadi ve İdari Bilimler Fakültesi Dergisi, 10(2), 69-96. http://iibfdergisi.gazi.edu.tr/index.php/iibfdergisi/article/viewFile/106/97

Arı, G. S. ve Bal, E. Ç. (2008). Tükenmişlik Kavramı: Birey ve Örgütler Açısından Önemi. Celal Bayar Üniversitesi İ. İ. B. F. Yönetim ve Ekonomi Dergisi, 15(1), 131-148. http://www.dergipark.ulakbim.gov.tr/yonveek/article/view/5000069206/5000064110

Atalay, İ. (2010). Mobbingin Örgütsel Bağlılık Üzerindeki Etkisi "Kamu Sektöründen Bir Örnek. (Yayımlanmamış yüksek lisans tezi). TC. Atılım Üniversitesi Sosyal Bilimler Enstitüsü, Ankara.

Avcı, N. ve Küçükusta, D. (2009). Konaklama İşletmelerinde Örgütsel Öğrenme, Örgütsel Bağlılık ve

İşten Ayrılma Eğilimi Arasındaki İlişki. Anatolia: Turizm Araştırmaları Dergisi, 20(1), 3344.

http://www.anatoliajournal.com/atad/depo/dergiler/Cilt20_Sayi1_Yil2009_1305116575.p df

Aygün, H. A. (2012). Psikolojik Yıldırma (Mobbing) Üzerine Nitel Bir Araştırma. Gümüşhane

Üniversitesi Sosyal Bilimler Elektronik Dergisi, 5, 92-121.

http://sbedergi.gumushane.edu.tr/Makaleler/314228041_sayi5-910HaciAliAygun5.pdf

Cammann, C. Fichman, M. Jenkins, D. and Klesh, J. (1979). The Michigan Organizational

Assessment Questionnaire. Unpublished Manuscript, University of Michigan: Ann Arbor.

Cemaloğlu, N. ve Şahin, D. E. (2007). Öğretmenlerin Mesleki Tükenmişlik Düzeylerinin Farklı

Değişkenlere Göre İncelenmesi. Kastamonu Eğitim Dergisi, 15(2), 465-484.

http://www.kefdergi.com/pdf/15_2/ncemaloglu.pdf

Çam, O. (1991). Hemşirelerde Tükenmişlik Ve Çeşitli Değişkenlere Göre İncelenmesi.

(Yayınlanmamış Doktora Tezi). Ege Üniversitesi, İzmir.

Çobanoğlu, S. (2005). İşyerinde Duygusal Saldırı ve Mücadele Yöntemleri. İstanbul: Timaş.

Davenport, N. , Schwardz, R. D. ve Elliott, G. P. (2003). Mobbing İşyerinde Duygusal Taciz, İstanbul:Sistem.

Demir, M. ve Tütüncü, Ö. (2010). Ağırlama İşletmelerinde Örgütsel Sapma ile İşten Ayrılma Eğilimi Arasındaki İlişki. Anatolia: Turizm Araştırmaları Dergisi, 21(1), 64-74.

http://www.anatoliajournal.com/atad/depo/dergiler/Cilt21_Sayi1_Yil2010_1304924579.p

df

Dikmetaş, E. , Top, M. ve Ergin, G. (2011). Asistan Hekimlerin Tükenmişlik ve Mobbing

Düzeylerinin İncelenmesi. Türk Psikiyatri Dergisi, 22(3), 137-149.

http://www.turkpsikiyatri.com/PDF/C22S3/137-149.pdf

Doğan, M. A. (2009). İlköğretim Okullarında Öğretmenlere Uygulanan Psikolojik Şiddetin (Mobbing)

İş Doyumuna Etkisi: Ankara İli Sincan İlçesi Örneği. (Yayımlanmamış yüksek lisans tezi).

T.C.Attlım Üniversitesi Sosyal Bilimler Enstitüsü, Ankara.

Erdirençelebi, M. ve Filizöz, B. (2016). Mobbingin Etik İklim ve Çalışanların İşten Ayrılma Niyeti

Üzerine Etkileri. Selçuk Üniversitesi Sosyal Bilimler Enstitüsü Dergisi, 35, 127-139.

dergisosyalbil.selcuk.edu.tr/susbed/article/download/1267/1053 
Ergin, C. (1993). Doktor ve hemşirelerde tükenmişlik ve Maslach Tükenmişlik Ölçeğinin uyarlanması. R. Bayraktar ve İ. Dağ (Ed.). Ankara:VII. Ulusal Psikoloji Kongresi Bilimsel Çalışmaları,VII. Ulusal Psikoloji Kongresi Düzenleme Kurulu ve Türk Psikologlar Derneği.

Ergin, C. (1996). Maslach Tükenmişlik Ölçeğinin Türkiye Sağlık Personeli Normları. 3P Dergisi,4(1), 28-33. http://www.turkmedline.net/degilistesi.php?journal=51

Filizöz, B. ve Ay, F. A. (2011). Örgütlerde Mobbing ve Tükenmişlik Olgusu Arasındaki İlişkilere Yönelik Bir Araştırma. e-Journal of New World Sciences Academy Social Sciences, 6(2), 229-241. dergipark.ulakbim.gov.tr/nwsasocial/article/download/5000061942/5000058388

Gaertner, S. (1999). Structural Determinants of Job Satisfaction and Organizational Commitment in Turnover Models. Human Resource Management Review, 9(4), 479-493. http://www.sciencedirect.com/science/article/pii/S1053482299000303

Göktürk, G. Y. ve Bulut, S. (2012). Mobbing:İsyerinde Psikolojik Taciz. Abant İzzet Baysal Üniversitesi Sosyal Bilimler Enstitüsü Dergisi, 1(24), 53-70. Doi: http://dx.doi.org/10.11616/AbantSbe.

Güllüce, A. Ç. ve Kaygın, E. (2013). Çalışanların Demografik Değişkenleri Açısından Tükenmişlik Düzeylerini Belirlemeye Yönelik Bir Araştırma. Atatürk Üniversitesi İktisadi ve İdari Bilimler

Dergisi, 27(2), 235-249.

http://e-dergi.atauni.edu.tr/atauniiibd/article/view/1025008679/1025007548

Kaçmaz, N. (2005). Tükenmişlik (Burnout) Sendromu. İstanbul Tıp Fakültesi Dergisi, 68(1), 29-32.

Kahumuza, J. ve Schlechter, A. F. (2008). Examing the Direct and Some Mediated Relationship between Perceived Support and Intention to Quit. Management Dynamics, 17(3), 2-19. http://reference.sabinet.co.za/document/EJC69740

Leymann, H. (1993). Mobbing Psychoterror Am Arbeitzplatz Und Wie Man Sich Dagegen Wehren Kann(Mobbing-Psychoterror At Work Places). Reinbek:Rowohlt.

Leymann, H. (1996). The Contend and Development of Mobbing at Work. European Journal of Work and Organizational Psychology, 5(2),165-184. http://www.choixdecarriere.com/pdf/6573/2010/Leymann1996.pdf

Maslach, C. ve Jackson, S.E. (1981). The Measurement Of Experienced Burnout. Journal of Organizational Behavior, 2(2), 99-113. Doi:10.1002/job.4030020205

Oğuzberk, M. ve Aydın A. (2008). Ruh Sağlığı Çalışanlarında Tükenmişlik. Klinik Psikiyatri Dergisi, 11, 167-179. apbs.mersin.edu.tr/files/arzu.aydin/Publications_009.pdf

Ok, S. (2002). Banka Çalışanlarının Tükenmişlik Düzeylerinin İş Doyumu, Rol Çatışması, Rol

Belirsizliği ve Bazı Bireysel Özelliklerine Göre İncelenmesi.(Yayımlanmamış doktora tezi). Hacettepe Üniversite Sosyal Bilimler Enstitüsü, Ankara.

Otacioğlu, S. G. (2008). Müzik Öğretmenlerinde Tükenmişlik Sendromu ve Etkileyen Faktörler. İnönü

Üniversitesi Eğitim Fakültesi Dergisi, $\quad 9(15), \quad$ 103-116. http://efdergi.inonu.edu.tr/article/view/5000004233/5000004746

Ören, N. ve Türkoğlu, H. (2006). Öğretmen Adaylarında Tükenmişlik. Muğla Üniversitesi Sosyal $\begin{array}{llll}\text { Bilimler Enstitüsü } & \text { Dergisi }\end{array}$ sobbiad.mu.edu.tr/index.php/asd/article/download/173/178.

Özler, D. E. , Atalay, C. G. ve Şahin, M. D. (2008). Mobbingin Örgütsel Bağlılık Üzerine Etkisini Belirlemeye Yönelik Bir Araştırma. Dumlupınar Üniversitesi Sosyal Bilimler Dergisi, 22 , 37-60.

https://birimler.dpu.edu.tr/app/views/panel/ckfinder/userfiles/17/files/DERG_/22/3760.pdf

Özyer, K. ve Orhan U. (2012). Akademisyenlere Uygulanan Psikolojik Tacize Yönelik Ampirik Bir Araştırma. Ege Akademik Bakış, 12(4), 511-518. http://www.acarindex.com/dosyalar/makale/acarindex-1423876817.pdf

Quine, L. (1999). WorkplaceBullying in NHS Community Trust Staff Questionnaire Survey. Medical Journal, 318, 228-232. https://www.ncbi.nlm.nih.gov/pmc/articles/PMC27703/ https://www.ncbi.nlm.nih.gov/pmc/articles/PMC27703/ 
Haluk Tanrıverdi \& Gelengül Koçaslan \& Nurdan Osmanoğlu Taştan / Psikolojik Şiddet Algısl, Tükenmişlik Sendromu Ve İșten Ayrılma Niyeti Arasındaki İlişki: Banka Çalışanları Üzerinde Bir

Araştırma

Simons, S. (2008). Workplace Bullying Experienced by Massachusetts Registered Nurses and The

Relationship to Intention to Leave The Organization. Advances in Nursing Science, 31,(2), 48-59. Doi: 10.1097/01.ANS.0000319571.37373.d7

Sökmen A. ve Mete E. S. (2015). Bezdirinin İş Performansı, İş Tatmini ve İşten Ayrılma Niyeti

Üzerindeki Etkisi: Ankara'da Bir Araştırma. Gazi Üniversitesi İ.İ.B.F. Dergisi, 17(3), 271-

295. http://iibfdergisi.gazi.edu.tr/index.php/iibfdergisi/article/view/913/638

Sünter, A. T. , Canbaz, S. , Dabak, S. , Öz, H. ve Peksen, Y. (2006). Pratisyen Hekimlerde

Tükenmişlik, İşe Bağlı Gerginlik ve İş Doyumu Düzeyleri. Genel Tıp Dergisi, 16(1), 9-14. http://www.geneltip.org/upload/sayi/47/GTD-00346.pdf

Şahin, F. (2011). Lider Üye Etkileşimi ile İşten Ayrılma Niyeti Arasındaki İlişki Üzerinde Cinsiyetin Etkisi. Ege Akademik Bakış Dergisi, 11(2), 277-288. http://www.acarindex.com/dosyalar/makale/acarindex-1423876886.pdf

Taslak, S. (2015). Banka Çalışanlarının İşten Ayrılma Niyetleri Üzerinde Etkili Olan Faktörlere

Yönelik Bir Araştırma: Muğla İli Örneği. Mehmet Akif Ersoy Üniversitesi Sosyal Bilimler Enstitüsü Dergisi, 7(12), 145-160. dergipark.ulakbim.gov.tr/makusobed/article/download/1098001184/1098000830

Taşpınar B. , Taşpınar F. , Güçlü S. , Nalbant A. , Çalık B. B. , Uslu A. ve Inal S. ( 2013). Investigation Of The Association Between Mobbing And Musculoskeletal Discomfort In Academicians. Japanese Psychological Research,55(4), 400-408. Doi: 10.1111/jpr.12030

Temizel, Y. (2013). Mobbing ve Türk Hukuk Sistemindeki Yeri. Adalet Dergisi, 45, 188-223. http://www.yayin.adalet.gov.tr/adaletdergisi/45.sayi/9_yavuz.pdf

Tett, R. P. ve Meyer, J. P. (1993). Job Satisfaction, Organizational Commitment, Turnover Intention and Turnover: Path Analyses Based on Meta Analytic Findings. Personel Psychology, 46(2), 259-293. Doi: 10.1111/j.1744-6570.1993.tb00874.x

Tınaz, P. ve Bayram, F. (2008). Çalı̧̧ma Psikolojisi ve Hukuki Boyutlarıyla İşyerinde Psikolojik Taciz (Mobbing). İstanbul: Beta.

Tümer, E. Ö. (2013). İşyerlerinde Psikolojik Taciz (Mobbing)”, İşyerlerinde Psikolojik Taciz (Mobbing) Bilgilendirme Rehberi. Ankara: Çalışma ve Sosyal Güvelik Bakanlığı.

Tümkaya, S. (1996). Öğretmenlerdeki Tükenmişlik, Görülen Psikolojik Belirtiler ve Başa Çıkma Davranışları. (Yayımlanmamış doktora tezi). Çukurova Üniversitesi, Adana.

Tütüncü, Ö. ve Demir, M. (2003). Konaklama İşletmelerinde İnsan Kaynakları Kapsamında İşgücü Devir Hızının Analizi ve Muğla Bölgesi Örneği. Dokuz Eylül Üniversitesi Sosyal Bilimler Enstitüsü $\quad$ Dergisi, $\quad 5(2), \quad 146-169$. http://www.sbe.deu.edu.tr/Dergi/cilt5.say\%C4\%B12/5.2\%20tutuncu\%20demir.pdf

Üngüren, E. , Doğan, H. , Özmen, M. ve Tekin, Ö. A. (2010). Otel Çalışanlarının Tükenmişlik ve İş Tatmin Düzeyleri İlişkisi. Journal of Yasar University, 17(5), 2922-2937. dergipark.ulakbim.gov.tr/jyasar/article/download/5000066089/5000061595

Yaman, E. (2009). Psikoşiddet (Mobbing) Ölçeği: Geçerlik ve Güvenirlik Çalışması. Kuram ve Uygulamada Eğitim Bilimleri, 9(2), 967-988. http://www.kuyeb.com/pdf/tr/178fd06342e5b31b7e2f41fb23c496bcanTAM.pdf

Yıldırım, M. H. ve İçerli, L. (2010). Tükenmişlik Sendromu: Maslach ve Kopenhag Tükenmişlik Ölçeklerinin Karşılaştırmalı Analizi. Organizasyon ve Yönetim Bilimleri Dergisi, 2(1), 123-131. http://sobiad.org/eJOURNALS/dergi_YBD/arsiv/2010_1/15mehmet_halit_yildirim.pdf

Yıldırım, M. H., Erul, E. E. ve Kelebek, P. (2014). Tükenmişlik İle İşten Ayrılma Niyeti Arasındaki İlişki Banka Çalışanları Üzerine Bir Araştırma. Organizasyon Ve Yönetim Bilimleri Dergisi, $\quad 6(1), \quad 34-44$. http://dergipark.ulakbim.gov.tr/oybd/article/view/5000145426/5000132772 


\section{SUMMARY}

Banks are one of the institutions where the negative effects of psychological violence, burnout syndrome and finally intention to leave are experienced. There is a growing literature studying psychological violence, burnout syndrome and intention to leave and their linkages.

The findings enable managers to observe these strong negative effects on employees and take precautions.

It is essential to create awareness against burnout syndrome and psychological violence in order to prevent from the negative effects in business life, health sector and economy. The paper gives information about psychological violence, burnout syndrome and intention to leave. Processes, specifications, reasons, consequences and how to cope with psychological violence, burnout syndrome and intention to leave are also specified in the paper.

The aim of this study is to search the relationship between psychological violence, burnout syndrome and intention to leave among bank employees.

The study includes a survey searching the perception of psychological violence, burnout syndrome and intention to leave. 243 Bank employees took part in the survey. Relationships between psychological violence, burnout syndrome and intention to leave are analyzed using SPSS 18; obtained datas are used in factor, correlation, regression, frequency analysis.

According to the results of the study, the general psychological violance level and the burnout level effect the rate of intention to leave. It is also shown that the general psychological violance level effects burnout level. 